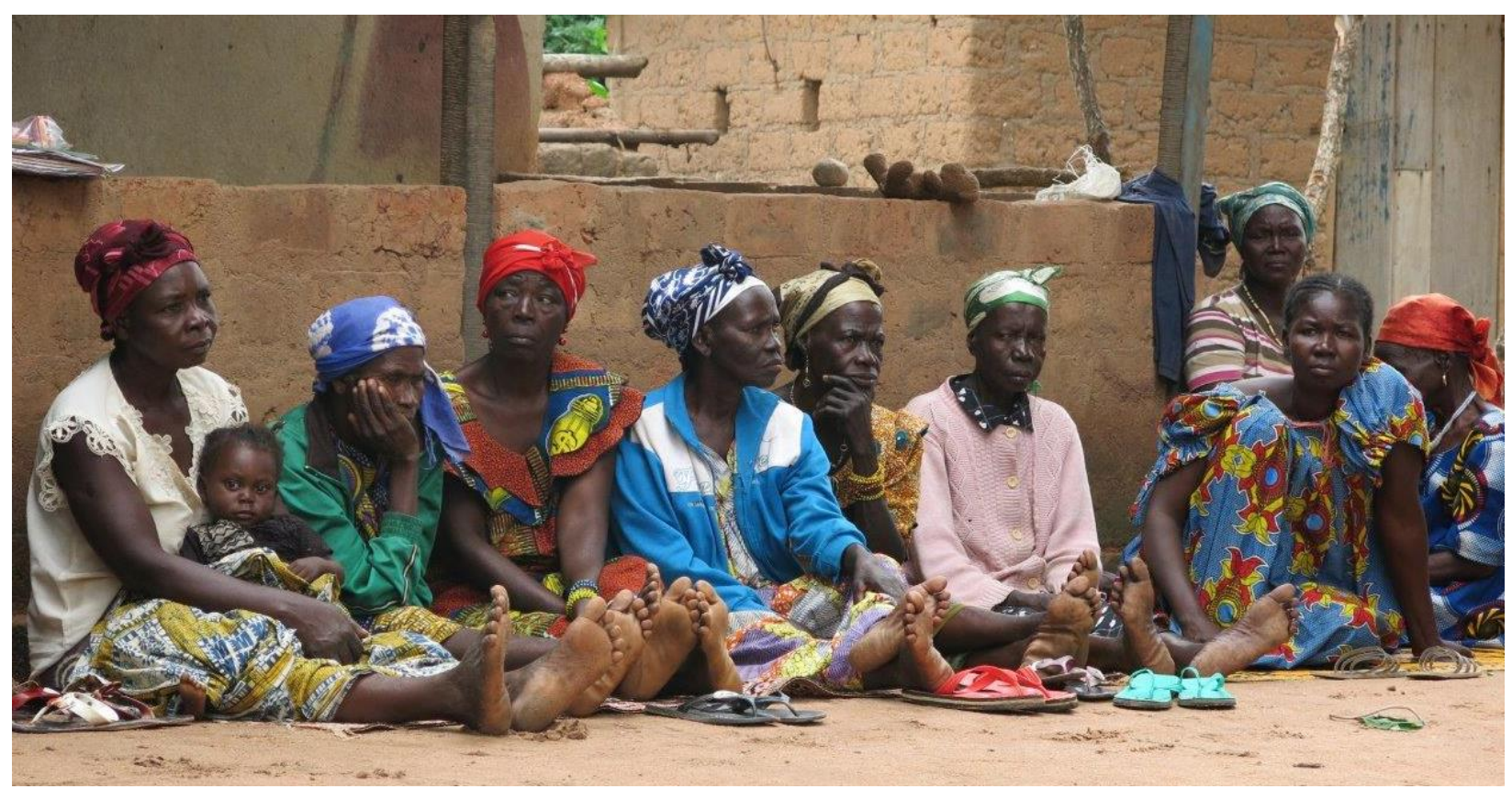

Photo: Oxfam/Paoua/October 2017

\title{
THE FUTURE OF CENTRAL AFRICAN REPUBLIC IS STILL AT RISK
}

More than half of Central African Republic's population is in need of urgent humanitarian aid - amidst chronic underfunding, persisting violence across the country and unsuccessful peace agreements. Donors must step up their commitments and meet their fair share responsibility of funding to stabilize the fragile situation. 
The security situation in the Central African Republic (CAR) is deteriorating and the humanitarian crisis is deepening, despite the peaceful democratic transition in 2016, the election of a new President and the presence of MINUSCA ${ }^{1}$ since 2014 . The situation remains volatile and insecure, with regular attacks on civilians, including targeted and indiscriminate attacks on humanitarian actors. The humanitarian needs are enormous, with more than half of the population, 2.5 million people, in need of protection and basic services. At the same time, the Humanitarian Response Plan received only $36.5 \%$ of funding, falling short of the needed $\$ 316 \mathrm{~m}^{2}$ The Humanitarian Response Plan for CAR in 2018 amounts to $\$ 518 \mathrm{~m}^{3}$

The worsening security situation in various parts of the country since May 2017 is creating instability and forcing vulnerable civilians to once again bear the brunt of the crisis. It has resulted in at least 249 arbitrary killings and more than 180,000 displaced persons. ${ }^{4}$ Today, 600,000 people are internally displaced and 482,000 are refugees in neighbouring countries. ${ }^{5}$ These are the highest levels reached since 2013 . To date, the population in need has grown from 2.2 million at the beginning of 2017 to 2.5 million. ${ }^{6}$ This level had not been reached since August 2014 and represents an increase of almost $50 \%$ since January 2017 . The renewal of the mandate of MINUSCA in November 2017, with an increase in capacity, will prove critical to improving the protection of civilians.

A year after the Donors' Conference in Brussels in November 2016, the humanitarian and development pledges made by the international community need to be translated into fresh commitments, and the government needs to show leadership to implement the National Recovery and Peacebuilding Plan (RCPCA 2017-2021).

A huge and concerted effort needs to be made by all stakeholders to consolidate progress, support peace and reconciliation and ensure that CAR does not revert back into a deeper crisis.

\section{THE PROTECTION OF CIVILIANS}

Conflict and violence resulting in forced displacement are spreading across CAR, engulfing territories that had been relatively safe and stable, while in other regions the status quo remains extremely fragile. ${ }^{7}$ Since May 2017 , the hotspots have multiplied, and renewed fighting in some areas of the country has already displaced more than 180,000 people for the year 2017 alone. ${ }^{8}$ Nearly $70 \%$ of the territory lies in the hands of armed groups. ${ }^{9}$

MINUSCA and the government, as the main protection actors, are struggling to fulfil their mandate. Government security forces are unable to ensure their presence over the whole of the country, let alone to protect the population. MINUSCA is overstretched and at times directly targeted by armed groups. The number of troops active outside of the capital Bangui is insufficient to cover the scope of the geographical areas affected by the conflict, and the resources to deploy for early action are limited. The population's perception of MINUSCA is poor. ${ }^{10}$ 
The renewal of MINUSCA's mandate and increase of capacity by 900 troops is a step in the right direction to address some of the deficiencies of the mission towards fulfilling its mandate on the protection of the civilians. However, troops still lack the capacity to deploy rapidly and fail to respond to attacks on civilians during violent clashes or killings, which is key to improving their acceptance with communities and is critical to the protection of civilians. ${ }^{11}$

Most of the time, civilians are left to fend for themselves and are exposed to many forms of violence. Men are generally more affected by arbitrary executions, arbitrary arrests and detentions, cruel, inhuman and degrading treatment, as well as extortion. ${ }^{12}$ More than 13,000 children are associated with armed groups. ${ }^{13}$ Women and girls are more affected by kidnappings, accusations related to witchcraft and sexual violence. In a population of 4.4 million, an estimated 97,000 women and girls are at risk of gender-based violence, including rape and sex slavery. ${ }^{14}$ Armed groups have committed sexual violence not simply as a by-product of fighting, but in many cases, as a tactic of war. ${ }^{15}$ Survivors face a lack of access to healthcare, psychosocial and socioeconomic support, making it extremely difficult to recover from trauma or to resume a normal life. ${ }^{16}$

As a consequence of violence, conflict and insecurity, the number of internally displaced persons (IDPs) rose to 600,000 in October 2017, for the first time since August 2014. In addition, 482,000 Central Africans are refugees in neighbouring countries - mainly in Cameroon, Democratic Republic of Congo, Chad and the Republic of Congo. Food insecurity and malnutrition is widespread: $48 \%$ of the population is suffering from hunger and receive a single meal per day, while 2.1 million people are severely food insecure. ${ }^{17}$

From January to August 2017, CAR accounted for one-third of the security incidents against NGOs worldwide, making it one of the countries where humanitarian workers are the most at risk. ${ }^{18}$ More than 200 acts of violence have been directed at humanitarian actors, and 13 humanitarian workers have been killed since the beginning of $2017 .{ }^{19}$ During the first quarter of $2017,28 \%$ of the security incidents recorded in CAR involved humanitarians: attacks, threats and plundering prevented humanitarian response in many areas, exacerbated the vulnerability of populations that could not be reached.

\section{Key messages}

- Oxfam calls on MINUSCA to focus its operational capacity on improving its performance on protecting civilians, through better information gathering, rapid deployment and action during violent clashes or killings. Furthermore, MINUSCA needs to urgently address the allegations of sexual abuse and exploitation and hold those responsible to account.

- Oxfam calls on all actors to end sexual violence against women and girls, and to ensure accessible and free-of-charge emergency health services for survivors and to support community-based reintegration programmes.

- Oxfam calls on the CAR government, with the support of donors and MINUSCA to gather national support and buy-in from all sides of the conflict to implement a medium- to long-term inclusive and comprehensive disarmament strategy to reduce violence in the country and address intercommunal conflicts.

- Following repeated attacks on humanitarian actors and humanitarian space, Oxfam calls on the CAR government, MINUSCA and armed groups to immediately respect the distinction between military, political and humanitarian actions, and to work together to improve the protection of humanitarian workers and to allow 
them full and unfettered humanitarian access to deliver aid to the most affected population.

- Oxfam calls on the CAR government to lead a domestic legal and operational framework with the support of international actors such as the ICRC and the African Union, based on the recommendations from the Kampala Convention for the protection of IDPs, and to work in partnership with humanitarian and development actors to ensure a principled response to displacement and to find durable solutions.

\section{PEACEBUILDING AND RECOVERY}

Progress on peacebuilding and recovery following the successful democratic elections in 2016 have been hampered by the escalation of violent incidents and intercommunal tensions across the country. The presence of more than a dozen armed groups represents an immediate obstacle to advancing stability and putting an end to the conflict. ${ }^{20}$ President Touadéra is determined to advance peacebuilding and national reconciliation through dialogue and to address the root causes of the conflict. However, he lacks both national and regional support in his endeavour. ${ }^{21}$

After a failed peace agreement in June 2017 under the auspices of the Sant'Egidio Community in Rome, the African initiative was launched in July 2017. Under the leadership of President Touadéra and co-supported by the African Union, ECCAS, and the International Conference on the Great Lakes Region (ICGLR) with the support of Angola, Chad, Congo and Gabon, the African Initiative constitutes the main framework for a political solution in the Central African Republic aiming to facilitate direct engagement between the parties. ${ }^{22}$

The African Initiative and the implementation of the National Recovery and Peacebuilding Plan need to work hand in hand to be effective, leveraging political, peacebuilding and recovery efforts and holistically addressing challenges that remain in terms of security, justice, reconciliation and socioeconomic development.

National and local civil society organizations can and should play a key role in the peace and reconciliation process, integrating gender equality and women's participation and empowerment as a priority and, where possible contributing to the humanitarian response through funding and technical support. They have expressed concerns over the deteriorating security and economic situation in the country, and the desire to participate in the peacebuilding process. ${ }^{23}$ The international community, donors and INGOs, should do more to promote local leadership in humanitarian response and the peacebuilding process.

\section{Key messages}

- Oxfam calls on national and regional stakeholders to support the government, to commit to the political and peace process through meaningful dialogue, and to increase diplomatic pressure on the parties to the conflict.

- Oxfam calls on the government to prioritize the engagement of women in instances of decision making, particularly in relation to peace building and economic recovery, and to ensure that ending gender-based violence is recognized as part of the peace process and that women's rights are sustained over the long term.

- In line with the Grand Bargain and the commitments made by the international 
community at the World Humanitarian Summit, donors must support local and national humanitarian actors and community-based organizations to enhance their meaningful participation in the peace process, their ability to better respond to recurrent crisis, and to meet the needs of the affected population.

\section{THE FUNDING GAP}

The humanitarian response faces chronic underfunding for life-saving needs. In the last five years, four donor conferences have been held in Brussels but have been ineffective in mobilizing sufficient funds to meet the needs of both humanitarian and development actors. ${ }^{24}$ The consequences of underfunding humanitarian crises are especially dire for the people who most in need of aid. Without sufficient funding, humanitarian operations are reduced, and humanitarian flight services, essential in delivering aid to hard-to-access areas are cut back, as is the delivery of food rations. ${ }^{25}$

The continuing deterioration of the situation in CAR has led the humanitarian community to revise its initial Humanitarian Response Plan (HRP) and increase the emergency appeal by 30\% to match growing humanitarian needs in 2017 .

The revised HRP now amounts to $\$ 497 \mathrm{~m}$ to cover basic humanitarian needs, and is currently funded at $35.6 \%$, falling short of $\$ 316 \mathrm{~m}$ to cover basic life-saving activities. ${ }^{26}$

CAR is far from the global level of funding for the humanitarian appeal, at $53 \% .{ }^{27}$ It has suffered from growing gaps in funding the annual humanitarian appeal in recent years, from 65\% funding received in 2014 to $36.5 \%$ in 2017 (see Figure 1). Despite severe and urgent humanitarian needs, and joint efforts from the humanitarian community, CAR is not a priority on the agenda of the international community. From 2014 to 2017, the HRP received respectively $68.2 \%, 53.5 \%, 37.9 \%$ and $36.5 \%$ of requested funds.

In this context of chronic underfunding, urgent needs remained uncovered in vital sectors such as protection, shelter and non-food items, water and sanitation, health, food security and nutrition. The lack of funding in these sectors means that newly displaced populations will lack access to shelter and will be unable to rebuild their livelihoods, making them dependent on aid. In parallel, efforts to strengthen early recovery and stabilization activities initiated with the launch of the RCPCA, need further effort to be operationalized on the ground. 
Figure 1: CAR funding trends 2017

\section{Central African Republic 2017}

https://fts.unocha.org/appeals/549/summary

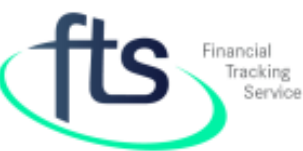

Trends in response plan/appeal requirements

07-DEC-2017

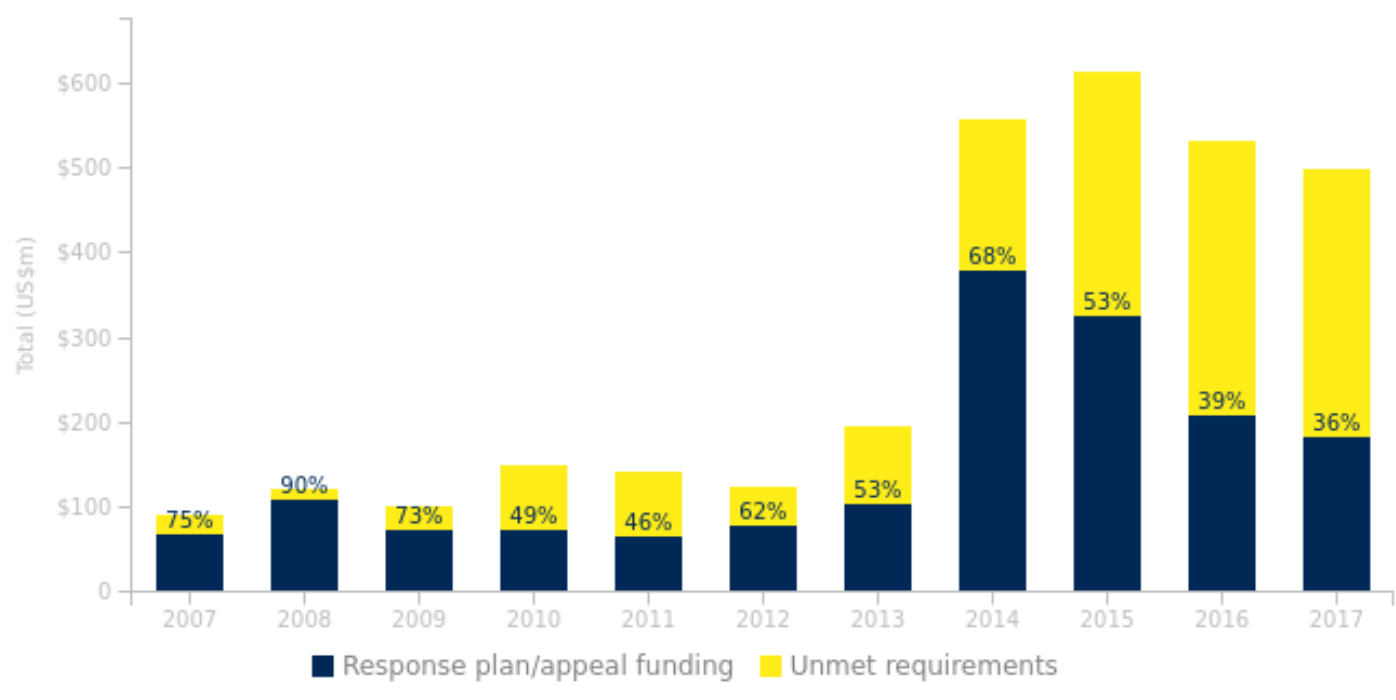

Amounts shown for the current year (far right bar) are for the year to date. No data is shown in years where there was no plan/appeal.

Figure 2: Status of CAR humanitarian funding

ธิ Funding Status (Humanitarian Response Plan)

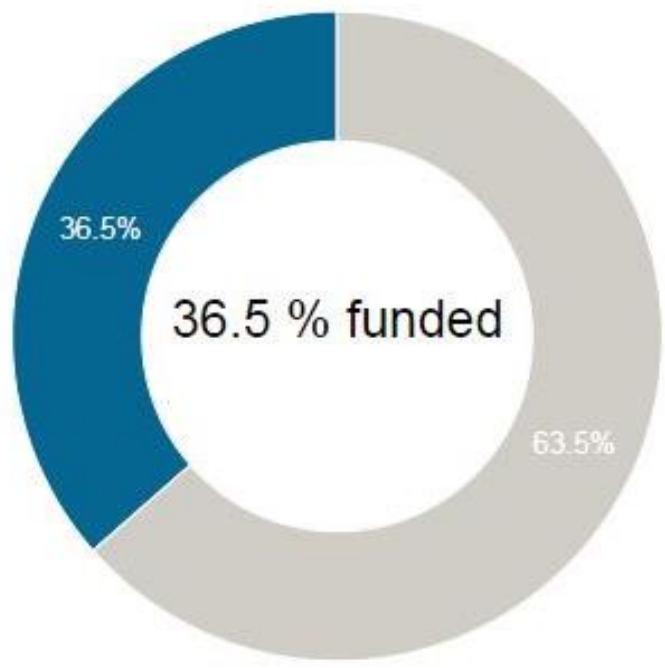

Total requirements:

$\$ 497.3 \mathrm{~m}$

Funding to date:

$\$ 181.4 \mathrm{~m}$

Funding gap:

$\$ 315.9 \mathrm{~m}$

The systematic underfunding of the CAR crisis heightens the risk of the country reverting into crisis because it is unable to stabilize, consolidate progress and have a positive impact on people's lives. ${ }^{28}$ The funding needs are complex and financial instruments need to be flexible, multi-year, and capable of adapting to short-, mediumand long-term needs. Funding needs to ensure that the affected population receives appropriate humanitarian and development support, at the same time as strengthening resilience capacities. 
In November 2016, donors and international organizations agreed the investment needs to implement the National Recovery and Peacebuilding Plan amounting to $\$ 1.6 \mathrm{bn}$ over the next three years and $\$ 3 \mathrm{bn}$ over five years. ${ }^{29}$ The actual pledges at the donor conference in Brussels reached a notable \$2.3bn (see Annexe 1 for the list of donors and pledges).

While the United Nations Security Council reports that $87 \%$ of the of the $\$ 2.3 \mathrm{bn}$ has been confirmed for the 2017-2019 period, there is no further information on its delivery or where these funds come from, and how they are applied to projects. ${ }^{30}$ For instance, the United States Administration pledged $\$ 11.7 \mathrm{~m}$ to support the justice sector, law enforcement, and economic livelihoods; but refers to already budgeted funds, not to additional funding.$^{31}$ Parts of the plan approved at the meeting consist of existing projects and budget support that was already scheduled. ${ }^{32}$

\section{Key messages}

- Donors must urgently increase their funding towards humanitarian response aimed at protecting civilians, especially vulnerable groups such as women, children and IDPs, including humanitarian response in protection, sexual and gender-based violence, early recovery and shelter.

- Donors must meet their commitment as per the revised 2017 HRP and the 2016 Brussels Donors' Conference. They must report and update their financial contributions in a transparent, public and voluntary way and ensure the funds are new commitments, not reassignment of budgeted funds.

- Donors must ensure that funding is flexible, multi-year and aligned to the HRP and the National Recovery and Peacebuilding Plan responding to humanitarian surges in the short term, peacebuilding and reconciliation efforts in the medium term and long-term development investments in a conflict and fragile setting.

\section{FAIR SHARE ANALYSIS}

Figure 3 below details the amount that high-income countries should be committing to the Central African Republic crisis response in 2017, based on the revised HRP. ${ }^{33}$

The analysis includes members of the OECD Development Assistance Committee (DAC) and high-income non-DAC countries. Each country's fair share is calculated as a percentage of the total appeal based on each country's combined gross national income (GNI). Each country's contributions to the appeal include both direct bilateral contributions and imputed multilateral funding.

The fair share analysis demonstrates that funding the CAR humanitarian crisis is not a priority for most donors.

- Contributions come from a very small number of donors, less than half contribute directly to HRP (16 donors in total, out of 33).

- Most donors make small contributions (75\% of donors' contributions are less than $\$ 10 \mathrm{~m}$, which represents $2 \%$ of the total humanitarian appeal).

- Only one-third of DAC countries (9 out of 27) fulfil their fair share of responsibility for funding of the humanitarian appeal in CAR. ${ }^{34}$

- More than half of donors (20 out of 33 donors) fulfil less than $50 \%$ of their fair share of responsibility for funding. 
Figure 3: Fair share analysis for funding the CAR humanitarian crisis

Calculations are based on other sheets - see "source" row for details

\begin{tabular}{|c|c|}
\hline REQUIRED FUNDS (\$m) & 497 \\
\hline DAC share (\%) & $60 \%$ \\
\hline DAC share (\$m) & 298 \\
\hline \% DAC Received & $82 \%$ \\
\hline Non-DAC Share (\%) & $35 \%$ \\
\hline Non-DAC Share (Sm) & 174 \\
\hline \% Non-DAC Received & $0 \%$ \\
\hline $\begin{array}{l}\text { Total \% of DAC and high } \\
\text { income non DAC } \\
\text { Required Funds Received }\end{array}$ & $49,20 \%$ \\
\hline
\end{tabular}

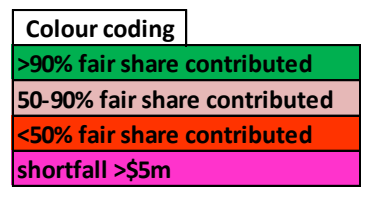

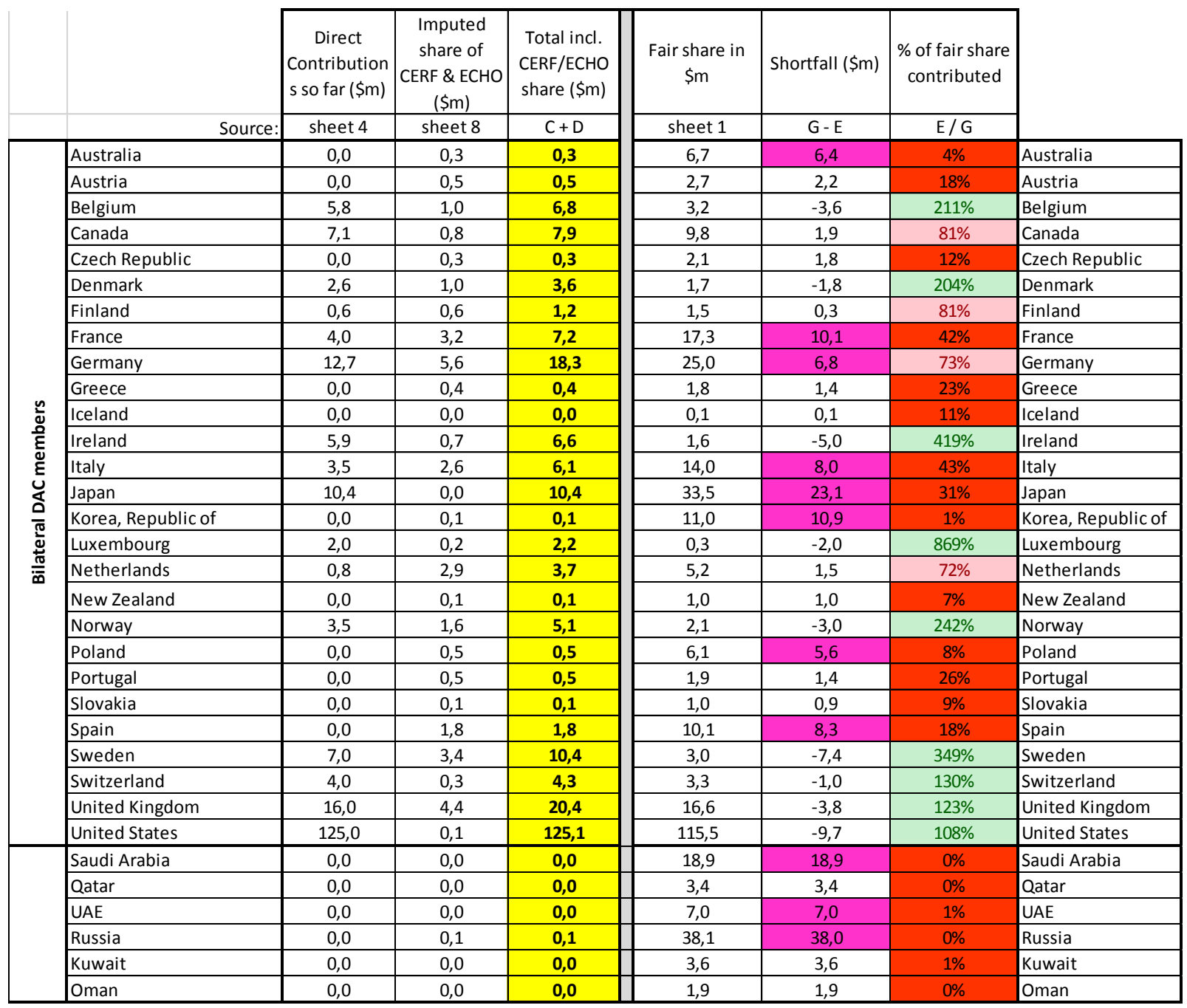

\section{METHODOLOGY}

The analysis uses the revised 2017 UN Humanitarian Response Plan for Central African Republic as an estimate of the total humanitarian needs. ${ }^{35}$ The analysis calculates the fair share for OECD Development Assistance Committee (DAC) countries and for high-income non-DAC countries. It uses each country's total GNI to establish each country's fair share. This analysis assumes that DAC countries, as a group, will collectively contribute $60 \%$ of the total amounts needed, and that highincome non-DAC countries will contribute $35 \%$. The remaining $5 \%$ is left unattributed to account for other sources of funding. The analysis tracks direct humanitarian 
contributions from each government, as well as imputed national shares of funding, where relevant, from the UN's Central Emergency Response Fund and the European Commission Humanitarian Office. Contributions have been calculated using publicly available sources from UN OCHA's Financial Tracking Service (FTS), and crosschecked with donor governments where possible. A more detailed explanation of the fair share methodology can be provided on request.

\section{DISCLAIMER}

1. The data analysis in this document was collected from the Financial Tracking System on 8 November 2017, and cross-checked with donors between the 31October and 15 November 2017.

2. Various Humanitarian Pool Funds and general bilateral donations that have not yet been published on the Financial Tracking Service (FTS website) have not been included above.

3. The analysis considers only funds that have been committed or paid. Pledges are not included.

4. The country's contribution may include humanitarian funding that is not included in the Humanitarian Response Plan for CAR in 2017.

5. At least two donors include funding to CAR refugees' crisis in neighbouring countries in their direct contribution to CAR humanitarian crisis.

6. The analysis above includes only contributions for humanitarian assistance, and as such, direct budget contributions to the Government of Central African Republic and un-earmarked contributions to UN institutions have not been included.

7. Where governments have been able to feed back directly on their humanitarian contributions in their own currency, these have been converted using a 2017 public exchange rate.

8. DAC members undertake specific reporting commitments for official development aid. Their commitment to reporting aid flows is reflected in high levels of engagement with non-DAC tracking systems such as OCHA's FTS. Non-DAC donors do not always have the same systems in place to track, monitor and report ODA, including humanitarian assistance. As a result, their engagement with the FTS has historically been less consistent, although Gulf donors in particular have increased their reporting efforts significantly over the past few years. Moreover, non-DAC donors do not necessarily subscribe to the same delineations for what constitutes ODA and more specifically humanitarian assistance, which has in some cases led non-DAC donors to seek to have direct budget contributions included as part of their fair share. Despite lower levels of reporting, the figures from the FTS have been used where available for reasons of consistency.

9. We acknowledge that countries might still increase their funding over the rest of the year. However, most countries had not met their fair share by the end of the year in 2017. 


\section{ANNEXE 1}

Table 1: Donor pledges for the National Peacebuilding and Recovery Plan (2017-2021)

\begin{tabular}{|c|c|c|c|c|c|c|}
\hline & Bailleur & Année & $\begin{array}{l}\text { Développement } \\
\text { et reconstruction } \\
\text { (M USD) }\end{array}$ & $\begin{array}{l}\text { Aide } \\
\text { humanitaire } \\
\text { (M USD) }\end{array}$ & $\begin{array}{l}\text { Autre } \\
\text { (M USD) }\end{array}$ & $\begin{array}{l}\text { Grand } \\
\text { Total } \\
\text { (M } \\
\text { USD) }\end{array}$ \\
\hline & $\mathbf{E U}$ & 2016-2020 & 389 & 38.5 & 22.5 & 450 \\
\hline \multirow{10}{*}{ 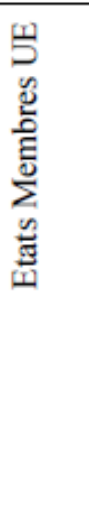 } & $\mathrm{CZ}$ & $2016-2018$ & & 0.3 & & 0.3 \\
\hline & $\mathrm{DE}$ & 2016-2017 & 20.4 & 16.5 & & 36.9 \\
\hline & IE & 2016-2018 & & 17.6 & & 17.6 \\
\hline & FR & $2017-2020$ & 118.0 & & & 118 \\
\hline & IT & $2016-2019$ & & 21.7 & & 21.7 \\
\hline & LUX & 2017-2019 & 6.7 & 7 & & 13.7 \\
\hline & NL & $2016-2020$ & 7.4 & 12.2 & & 19.6 \\
\hline & $\mathrm{SE}$ & 2016 & & 20 & & 20 \\
\hline & UK/DFD & $2016-2018$ & & 80 & & 80 \\
\hline & $\begin{array}{l}\text { Total EM } \\
\text { UE }\end{array}$ & & 152.5 & 175.3 & & 327.8 \\
\hline \multirow{6}{*}{ 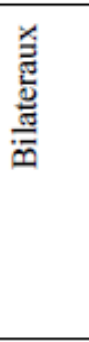 } & Japan & & & 1.5 & & 1.5 \\
\hline & Switzerland & 2016-2017 & & 13.4 & & 13.4 \\
\hline & US & & 11.7 & & & 11.7 \\
\hline & Timor Lest & & & 1.5 & & 1.5 \\
\hline & Norway & & & 5.5 & & 5.5 \\
\hline & $\begin{array}{l}\text { Total } \\
\text { Bilateraux }\end{array}$ & & & & & 33.6 \\
\hline \multirow{7}{*}{ 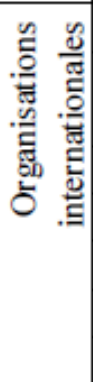 } & AfDB & & 400 & & & 400 \\
\hline & $\begin{array}{l}\text { Arab Bnaks } \\
\text { and Funds }\end{array}$ & & 391 & & & 391 \\
\hline & BDEAC & & 34.9 & & & 34.9 \\
\hline & CEMAC & & 30.1 & & & 30.1 \\
\hline & IMF & & 115.8 & & & 115.8 \\
\hline & WB & $2016-2020$ & 500 & & & 500 \\
\hline & Total OI & & 1471.7 & & & 1471.7 \\
\hline
\end{tabular}

Source : Conférence de Bruxelles, 30 Novembre 2016. $11^{\mathrm{e}}$ Fonds Européen de Développement, Programme indicatif National, 2014-2020.36

\section{NOTES}

1 United Nations Multidimensional Integrated Stabilization Mission in the Central African Republic. https://minusca.unmissions.org/en

2 UN OCHA Financial Tracking System. https://fts.unocha.org/countries/43/summary/2017 Last checked on 7 December 2017.

3 The Global Humanitarian Overview for 2018 was launched in December 2017, with a Humanitarian Response Plan for CAR of $\$ 518 \mathrm{~m}$. http://interactive.unocha.org/publication/globalhumanitarianoverview/

4 HRW. (27 October 2017). Central African Republic: Civilians targeted as Violence surges. https://www.hrw.org/news/2017/10/27/central-african-republic-civilians-targeted-violence-surges UN OCHA, Aperçu Humanitaire. The number of IDPs in May 2017 was 426,000.

https://reliefweb.int/sites/reliefweb.int/files/resources/rca_ocha_0517_apercu_humanitaire.pdf 
5 UN OCHA Apercu Humanitaire, Octobre 2017.

https://reliefweb.int/sites/reliefweb.int/files/resources/rca_ocha_141017_apercu_humanitaire.pdf, last viewed on 7 December 2017.

6 UN OCHA Apercu Humanitaire, Octobre 2017.

https://reliefweb.int/sites/reliefweb.int/files/resources/rca_ocha_141017_apercu_humanitaire.pdf, last viewed on 7 December 2017.

7 International Crisis Group (September 2017). Avoiding the Worst in Central African Republic. REPORT 253/AFRICA 28 SEPTEMBER 2017. https://www.crisisgroup.org/africa/central-africa/central-african-republic/253-avoiding-worstcentral-african-republic

8 According to OCHA's Humanitarian Snapshot, the number of IDPs in February 2017 amounted to 402,000. According to OCHA's Humanitarian Snapshot of October 2017, the number of IDPs had increased to 600,000. See: UN OCHA, Aperçu Humanitaire 20 Fevrier 2017. https://reliefweb.int/sites/reliefweb.int/files/resources/rca_ocha_170217humanitarian_snapshot.pdf

UN OCHA, Aperçu Humanitaire Octobre 2017, https://reliefweb.int/sites/reliefweb.int/files/resources/rca_ocha_141017_apercu_humanitaire.pdf

9 Institute for Security Studies (October 2017). Challenges ahead for the AU roadmap on the CAR. https://issafrica.org/pscreport/on-the-agenda/challenges-ahead-for-the-au-roadmap-on-the-car, Last viewed 13 November 2017.

10 Human Rights Council (September 2017). Report of the Working Group on the use of mercenaries as a means of violating human rights and impeding the exercise of the right of peoples to self-determination on its mission to the Central African Republic. 12 September 2017. http://www.ohchr.org/EN/HRBodies/HRC/RegularSessions/Session36/Documents/A_HRC_36_47_Add.1.docx Last viewed 13 November 2017.

11 United Nations Meeting Coverage and Press Release (November 2017). Unanimously Adopting Resolution 2387 (2017) Security Council Extends Mandate, Increases Troop Levels of Stabilization Mission in Central African Republic. 15th of November 2017. https://www.un.org/press/en/2017/sc13068.doc.htm and United Nations Security Council Resolution 2387, 15 November 2017. https://www.un.org/press/en/2017/sc13068.doc.htm

12 UN OCHA, Humanitarian Needs Assessments 2017. https://reliefweb.int/sites/reliefweb.int/files/resources/rca_ocha_2017_hno.pdf

13 UN OCHA, Humanitarian Needs Assessments 2017. https://reliefweb.int/sites/reliefweb.int/files/resources/rca_ocha_2017_hno.pdf

14 UN OCHA, Humanitarian Needs Assessments 2017; Human Right Watch (October 2017). Sexual Violence by Armed Groups in the Central African Republic. https://www.hrw.org/report/2017/10/05/they-said-we-are-theirslaves/sexual-violence-armed-groups-central-african. Last viewed 8 November 2017.

https://reliefweb.int/sites/reliefweb.int/files/resources/rca_ocha_2017 hno.pdf

15 Human Right Watch (October 2017). Sexual Violence by Armed Groups in the Central African Republic. https://www.hrw.org/report/2017/10/05/they-said-we-are-their-slaves/sexual-violence-armed-groups-central-african. Last viewed on 8 November 2017.

16 Human Right Watch (October 2017). Op cit.

17 World Food Program (September 2017). Country Brief, Central African Republic. http://documents.wfp.org/stellent/groups/public/documents/ep/wfp272236.pdf?_ga=1.204128592.1785065870.1480 060278

18 International NGO Safety: 30\% of NGO incidents happened in Central African Republic from Jan. 2016 to Sept 2017. http://www.ngosafety.org/keydata-dashboard/ Last viewed 22 November 2017.

19 UN OCHA, Note de presse (November 2017). Le Coordonnateur humanitaire condamne la dernière attaque qui a couté la vie à un humanitaire. https://reliefweb.int/report/central-african-republic/le-coordonnateur-humanitairecondamne-la-derni-re-attaque-qui-cout. Last viewed 13 November 2017.

20 https://minusca.unmissions.org/en/conclusions-high-level-meeting-political-security-and-humanitarian-situationcentral-african

21 UN Security Council (October 2017). Report of the Secretary-General on the Central African Republic. 18 Octobre 2017. http://www.un.org/ga/search/view_doc.asp?symbol=S/2017/865+\&Submit=Search\&Lang=E and ICG (September 2017). Avoiding the Worst in Central African Republic. https://d2071andvip0wj.cloudfront.net/253avoiding-the-worst-in-central-african-republic.pdf Africa Report n253, 28 September 2017.

22 https://minusca.unmissions.org/en/conclusions-high-level-meeting-political-security-and-humanitarian-situationcentral-african

23 Messages from workshop with close to 30 civil society organization representatives in CAR, organized with Oxfam on 14 November 2017.

24 Oxfam (2016). From Pledge to Commitment. Oxfam Policy Brief. https://www.oxfam.org/sites/www.oxfam.org/files/bn-car-pledge-to-commitment-151116-en_0.pdf

25 UN Call for Action, June 2017. https://reliefweb.int/sites/reliefweb.int/files/resources/CAR\%20Call\%20For\%20Action\%2017 05 30\%20final.pdf

26 UN OCHA (2017). Humanitarian Response Plan 2017-2019. Central African Republic. https://www.humanitarianresponse.info/system/files/documents/files/rca_ocha_0617_hrprevise_final.pdf. Last viewed 24 November 2017.

27 Ibid. 
28 Oxfam (2016). From Pledge to Commitment. Oxfam Policy Brief. https://www.oxfam.org/sites/www.oxfam.org/files/bn-car-pledge-to-commitment-151116-en_0.pdf

29 https://eeas.europa.eu/headquarters/headquarters-homepage/15251/international-donors-pledge-over-eu2-blncentral-african-republic-brussels-conference_en

30 United Nations Security Council Resolution 2387, 15 November 2017. https://www.un.org/press/en/2017/sc13068.doc.htm and ICG (2017). Avoiding the Worst in Central African Republic. https://d2071andvip0wj.cloudfront.net/253-avoiding-the-worst-in-central-african-republic.pdf, Africa Report no253, 28 September 2017.

31 https://fas.org/sgp/crs/row/R43377.pdf

32 ICG (2017). Avoiding the Worst in Central African Republic. Op. cit.

33 The World Bank defines high-income countries as those with GNI per capita of over \$12,235 in 2017.

34 See the methodology for more information on the fair share methodology and analysis.

35 UN OCHA (2017). Aperçu des Besoins Humanitaires, République Centre Africaine, 2017. https://www.humanitarianresponse.info/system/files/documents/files/rca_ocha_171123_hno_french.pdf

36 Conférence de Bruxelles, 30 Novembre 2016. 11e Fonds Européen de Développement, Programme indicatif National, 214-2020, p.31 https://ec.europa.eu/europeaid/sites/devco/files/nip-car-fed11-2017_fr.pdf

(c) Oxfam International January 2018.

This paper was written by Amelie Gauthier. Oxfam acknowledges the assistance of Sylvia Ghaly and Paula San Pedro in its production. It is part of a series of papers written to inform public debate on development and humanitarian policy issues.

For further information on the issues raised in this paper please email advocacy@oxfaminternational.org

This publication is copyright but the text may be used free of charge for the purposes of advocacy, campaigning, education, and research, provided that the source is acknowledged in full. The copyright holder requests that all such use be registered with them for impact assessment purposes. For copying in any other circumstances, or for re-use in other publications, or for translation or adaptation, permission must be secured and a fee may be charged. Email policyandpractice@oxfam.org.uk.

The information in this publication is correct at the time of going to press.

Published by Oxfam GB for Oxfam International under ISBN 978-1-78748-156-5 in January 2018. DOI: $10.21201 / 2017.1565$

Oxfam GB, Oxfam House, John Smith Drive, Cowley, Oxford, OX4 2JY, UK.

\section{OXFAM}

Oxfam is an international confederation of 20 organizations networked together in more than 90 countries, as part of a global movement for change, to build a future free from the injustice of poverty. Please write to any of the agencies for further information, or visit www.oxfam.org

$\begin{array}{ll}\text { Oxfam America (www.oxfamamerica.org) } & \text { Oxfam India (www.oxfamindia.org) } \\ \text { Oxfam Australia (www.oxfam.org.au) } & \text { Oxfam Intermón (Spain) (www.oxfamintermon.org) } \\ \text { Oxfam-in-Belgium (www.oxfamsol.be) } & \text { Oxfam Ireland (www.oxfamireland.org) } \\ \text { Oxfam Brasil (www.oxfam.org.br) } & \text { Oxfam Italy (www.oxfamitalia.org) } \\ \text { Oxfam Canada (www.oxfam.ca) } & \text { Oxfam Japan (www.oxfam.jp) } \\ \text { Oxfam France (www.oxfamfrance.org) } & \text { Oxfam Mexico (www.oxfammexico.org) } \\ \text { Oxfam Germany (www.oxfam.de) } & \text { Oxfam New Zealand (www.oxfam.org.nz) } \\ \text { Oxfam GB (www.oxfam.org.uk) } & \text { Oxfam Novib (Netherlands) (www.oxfamnovib.nl) } \\ \text { Oxfam Hong Kong (www.oxfam.org.hk) } & \text { Oxfam Québec (www.oxfam.qc.ca) } \\ \text { Oxfam IBIS (Denmark) (www.ibis-global.org) } & \text { Oxfam South Africa (www.oxfam.org.za) }\end{array}$

